\begin{tabular}{|l|l|l|}
\hline \multicolumn{2}{|c|}{ PublisherInfo } \\
\hline \hline PublisherName & $:$ & BioMed Central \\
\hline \hline PublisherLocation & $:$ & London \\
\hline \hline PublisherImprintName & $:$ & BioMed Central \\
\hline \hline
\end{tabular}

\title{
The power of the electronic thesis
}

\begin{tabular}{|l|l|l||}
\hline \multicolumn{2}{|c|}{ ArticleInfo } \\
\hline \hline ArticleID & $:$ & 4032 \\
\hline \hline ArticleDOI & $:$ & $10.1186 /$ gb-spotlight-20010402-01 \\
\hline \hline ArticleCitationID & $:$ & spotlight-20010402-01 \\
\hline \hline ArticleSequenceNumber & $:$ & 103 \\
\hline \hline ArticleCategory & $:$ & Research news \\
\hline ArticleFirstPage & $:$ & 1 \\
\hline \hline ArticleLastPage & $:$ & 3 \\
\hline \hline & & RegistrationDate : 2001-04-02 \\
ArticleHistory & $:$ & OnlineDate $\quad$ 2001-04-02 \\
\hline \hline ArticleCopyright & $:$ & BioMed Central Ltd2001 \\
\hline \hline ArticleGrants & $:$ & \\
\hline \hline ArticleContext & $:$ & 130592211 \\
\hline \hline
\end{tabular}


PASADENA The Fourth International Symposium on Electronic Theses and Dissertations, ETD 2001, concluded on 24 March with a call for more academic institutions to make theses and dissertations available online. Eric Van de Welde, chair of the symposium program committee, stressed the importance of increasing access to these works: "the exchange of ideas is the currency of scholarly enterprise."

Electronic theses and dissertations (ETDs) consist of masters or doctoral research work that is submitted or archived electronically by an institution, either on an internal network or on the web. Although most ETDs are currently formatted as straight text documents, the electronic medium offers enormous flexibility and can support multimedia, animation and interactive features.

Representatives from more than 15 nations attended the symposium. Many of those visiting from developing countries were sponsored by UNESCO, which is currently setting up international guidelines for ETDs via the Digital Media Institute. UNESCO is committed to the free flow of scientific information and promoting the internet as a tool for disseminating scientific knowledge. The UNESCO guide aims to standardize formats and archiving of ETDs internationally and to facilitate the setting up of ETD systems at individual institutions. "ETDs are crucial for creating an open and democratic information society," said Axel Plathe, UNESCO representative at the conference.

Institutions in the US are pioneering the use of ETDs and several have been encouraging their students to submit electronically for a number of years. Virginia Tech was the first university to set up an ETD service and now has more than 3000 theses stored and searchable via the internet. In 1997, it made electronic submission of theses from masters and doctoral candidates mandatory. Many of the university representatives attending the conference were, however, still initiating schemes or in their first year of accepting voluntary ETD submissions. For these attendees, there were still issues of copyright, access and submission procedures to address.

The NDLTD (Networked Digital Library of Theses and Dissertations) - the international consortium that organised the conference - is now hoping to develop a central website that will enable visitors to browse through ETDs from any university that makes its research available online. The NDLTD promotes digital libraries of ETDs and already has more than 100 universities and professional organisations as members. "If universities want the world to see the research of their students it is vital that they start producing ETDs," concluded Edward Fox, director of the NDLTD. 


\section{References}

1. Fourth International Symposium on Electronic Theses and Dissertations, ETD 2001, [http://library.caltech.edu/etd/]

2. Digital Media Institute, [http://www.etdguide.org/]

3. Virginia Tech ETD guide, [http://etd.vt.edu/]

4. Networked Digital Library of Theses and Dissertations, [http://www.ndltd.org/]

5. NDLTD - ETD Digital Library, [http://www.theses.org/]

This PDF file was created after publication. 